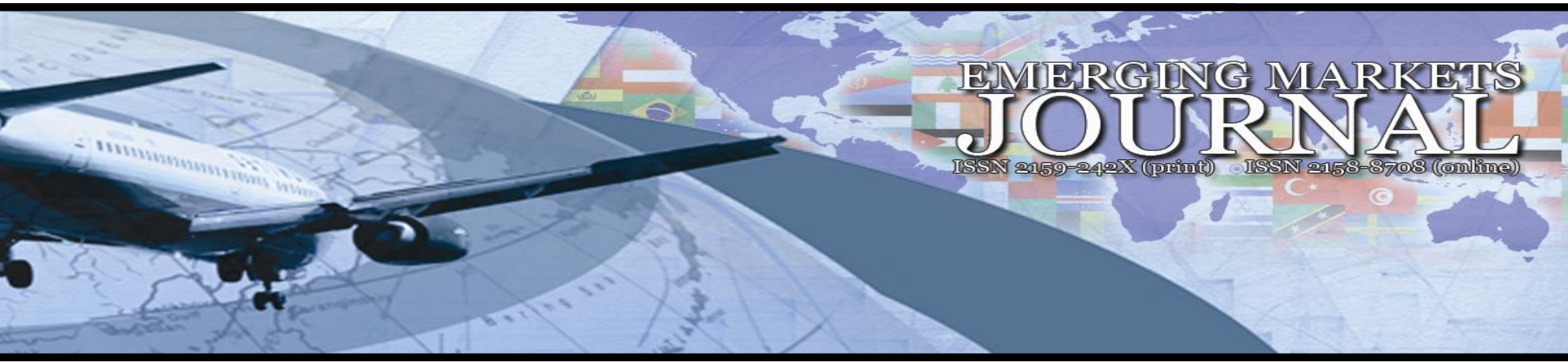

\title{
The Perception of Teachers about Financial Markets and Instruments Information
}

\section{Ferhat Sayım}

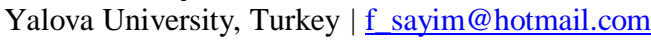

Nurdan Serdar

Yalova University, Turkey | nurdanserdar4@gmail.com

Volume 9 No 2 (2019) ｜ ISSN 2158-8708 (online) ｜ DOI 10.5195/emaj.2019.186 | http://emaj.pitt.edu |

\begin{abstract}
In recent years, online shopping, online financial transactions and social media have become a subject of interest to everyone. Current economic news and economic developments are being interpreted by all. In addition, individuals constitute the class of consumers as the most important element of microeconomics. Also regardless of profession, individuals carry out entrepreneurial activities and constitute economic units such as firms and so on. The public's so much interconnectedness with the economy is normal, and this interest has been the subject of more research in academic circles in recent years. Many researches have been done on measuring the financial literacy of various public sectors. Various scales have been prepared. The financial literacy of teachers, who are the main component of education system, is very important both in terms of the large professional community they represent and in terms of the student population they train. In this aspect, teachers' familiarity with financial systems and concepts, how they make sense of them in their daily lives have been seen as a subject worth investigating. The scales of financial literacy studies are examined in the literature. Also, the scale of the measurement of the level of financial knowledge felt towards the business environment other than financial literacy has been examined. A new scale has been prepared that includes the main elements of these two basic scales. A survey has been conducted in various subtitles that do not exceed one page. The questionnaire was applied to teachers in schools. It is given high importance that they fill the questionnaire with the researcher. Data which transmitted in excel are tried to be interpreted through the SPSS program. The survey contains sub-headings and will serve as the basis for more than one study. Teachers' knowledge of the financial system is as low as expected. When applying the questionnaire, teachers talk about realizing that they don't really know some of the concepts they use in everyday life. However, it is observed that the information levels are increasing about some focus issues. Data related teachers' financial literacy, such as the functioning of the financial system, recognizing financial institutions, recognizing financial instruments, recognizing and making financial transactions are gathered. Summary tables have been created. In this study, teachers' familiarity with financial concepts is explained.
\end{abstract}

Keywords: Financial market, financial literacy, teachers

New articles in this journal are licensed under a Creative Commons Attribution 3.0 United States License.

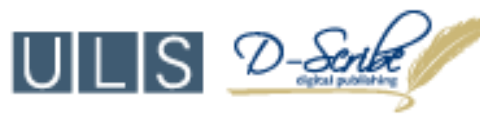

This journal is published by the University Library System of the University of Pittsburgh as part of its $\underline{\mathrm{D} \text {-Scribe Digital Publishing Program, and is cosponsored by the University of Pittsburgh Press. }}$. 


\section{The Perception of Teachers about Financial Markets and Instruments Information*}

\section{Ferhat Sayım Nurdan Serdar}

\section{Introduction}

In recent years, online shopping, online financial transactions and social media are becoming more common. Thus, these subjects have become a subject of interest to everyone. Current economic news and economic developments are being interpreted by all. In addition, individuals constitute the class of consumers as the most important element of microeconomics. Besides that, the dominance of teachers, who take the task of training people, about existing knowledge, capabilities and the opinions they convey to the students have a great importance. Measuring teachers' level of knowledge of financial concepts which is related with everyone even in different levels is accepted as valuable for themselves and for the potential achievements of students with whom they are in continuous communication. The perception of information that teachers feel about financial concepts is the subject of research. The studies in the literature are more focused on financial literacy and many are applied to students. Another study topic consists of financial behavior and attitudes.

\section{Literature}

Similar research have been examined in the literature. In the examination, the level of financial literacy, determination of financial behavior, attitudes and the importance of financial education studies were found. While financial literacy studies on students are at the forefront of research estimating a particular segment, there are also studies on the financial skills and education of women. No study that measures teachers' relationships with financial concepts or the financial sector was found in the research.

A close and common research topic as a subject is the research about financial literacy. These research and their results have been examined, but it has been observed that the population is usually the segments of students, public sector etc. Their interest in financial information, financial attitudes and financial behavior have been investigated (Coşkun, 2016, 2247-2258) (Bayram, 2014, pp. 105-135) (Alkaya \& Yağlı, 2015).

\footnotetext{
This study was previously presented in The International Conference of Business Students (ICOBS-2019) as a paper in a different language.
}

The Financial Literacy and Access Association and Visa conducted the Turkish Financial Literacy Survey to determine the level of financial literacy of the general public and to understand attitudes and behaviors towards financial products and services. The research was carried out face-to-face with 2,000 people in 26 provinces in Turkey between January and February 2019. Participants were asked 10 questions about the level of financial literacy, including both math transaction information and inflation and risk perception, and those who answered at least 7 of these 10 questions correctly were identified as financial literacy. According to the research results, the financial information score increased from 70 percent in 2017 to 75 percent in 2019 , meaning that the correct response to a minimum of 7 . According to the results, the level of financial literacy has increased.(Financial Literacy and Access Association)

Another research, "Finansal Okuryazarlık: Harran Üniversitesi Suruç Meslek Yüksekokulu Öğrencilerine Yönelik Bir Araştırma ", is a study of students studying at Harran University Suruc Vocational School in 2017-2018. Literacy levels, basic and current financial indicators and simple interest calculations have been tried to be examined (Aba Şenbayram, 2019, p. 3).

"Finansal Eğitimin Finansal Okur-Yazarlık Üzerindeki Etkisi: Muğla İlinde Kadınlara Yönelik Bir Araştırma" tried to demonstrate the impact of education on financial literacy in investments by comparing women's financial literacy levels with financial education (Bayrakdaroğlu \& Bilge, 2018, p. 114).

The article titled "Üniversite Öğrencilerinin Finansal Okuryazarlık Düzeylerinin Bazı Demografik Değişkenler Açısından İncelenmesi" is one of the studies in the literature. It is seen as a goal to educate young people who are capable of making financial decisions in a healthy way, are conscious of credit card use and can manage their budget. In this context, it is stated that education in financial subjects in Turkey should be added to the curriculum in the years of compulsory education and in higher education institutions as compulsory courses in faculties other than The Faculty of Administrative Sciences and Economics. (Yücel \& Çiftçi, 2018, p. 159)

\section{Methodolgy}

\section{The Importance of Research-Method}

Even though they are in different levels doing individual entrepreneurial activities, creating economic units such as firm etc. are in financial system. Teachers are not only individuals, but teachers are also a key element of the education system. Their financial situation affects a large number of other individuals, considering the students they educate and benefit society. For these reasons, measuring the perception of information about the financial market and instruments of teachers is a subject worth for investigating. 
In this study, the level of knowledge that teachers define for themselves about the financial system and concepts is investigated with questionnaires that do not exceed one page. This level of knowledge is not a measurement of information that can be measured parametrically. How the surveyed audience defines their level of knowledge about the financial concept is investigated. They are given three options. $0=\mathrm{I}$ don't know anything about that. $1=\mathrm{I}$ have general knowledge of this subject $2=\mathrm{I}$ have more detailed knowledge such as Risk, Cost and Returns. The data obtained were evaluated in the statistics program and were tested with reliability test for non-parametric data. In the analysis, the outputs which are processed in Excel and obtained by tabulating the data in the SPSS program were used.

Universe and Sampling (Scope)

Sectoral Distribution

It can be said that the sample has a balanced distribution for the public and private sectors. This independent variable is divided into two sub-groups.

Table 1. Public and Private Sector Distribution

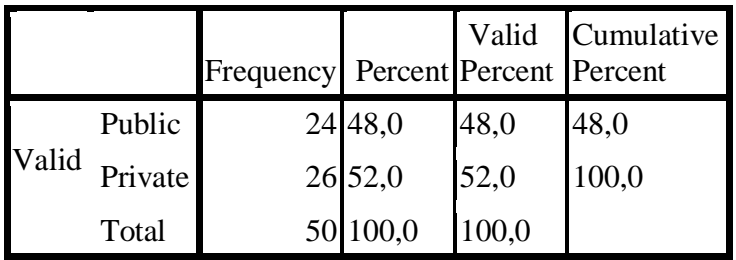

\section{Age Distribution}

The distribution based on age was divided into four sub-groups. While participants under 30 and 31-40 years are in majority, the proportions of groups aged 41 50 and over 50 are close to each other.

Table 2. Distribution by Age

\begin{tabular}{|c|l|l|l|l|}
\hline & Frequency & Percent & $\begin{array}{l}\text { Valid } \\
\text { Percent }\end{array}$ & $\begin{array}{l}\text { Cumulative } \\
\text { Percent }\end{array}$ \\
\hline Under & 16 & 32,0 & 32,0 & 32,0 \\
Valid 30 & & & & \\
$31-40$ & 17 & 34,0 & 34,0 & 66,0 \\
$41-50$ & 9 & 18,0 & 18,0 & 84,0 \\
Over 50 & 8 & 16,0 & 16,0 & 100,0 \\
Total & 50 & 100,0 & 100,0 & \\
\hline
\end{tabular}

\section{Gender Distribution}

When the distribution of the participants by gender is examined, women are in majority with a difference that does not pose a problem in terms of feasibility analysis.
Table 3. Distribution by Gender

\begin{tabular}{|c|r|r|r|r|}
\hline & Frequency & Percent & $\begin{array}{l}\text { Valid } \\
\text { Percent }\end{array}$ & $\begin{array}{l}\text { lumulative } \\
\text { Percent }\end{array}$ \\
\hline Valid Men & 21 & 42,0 & 42,0 & 42,0 \\
Woman & 29 & 58,0 & 58,0 & 100,0 \\
Total & 50 & 100,0 & 100,0 & \\
\hline
\end{tabular}

\section{Reliability Test}

Cronbach alpha is 0.910 for the questionnaire, which seeks to measure the perception of information that teachers feel about financial instruments and concepts. This coefficient is sufficient for the study to be analyzed.

Table 4 . Reliability Test

\begin{tabular}{|c|c|c|c|c|}
\hline \multicolumn{2}{|l|}{ Cronbach's Alpha } & \multicolumn{3}{|c|}{$\mathrm{N}$ of Items } \\
\hline & 910 & & & 17 \\
\hline & $\begin{array}{r}\text { Scale } \\
\text { Mean } \\
\text { if } \\
\text { Item } \\
\text { Delet } \\
\text { ed }\end{array}$ & $\begin{array}{r}\text { Scale } \\
\text { Varia } \\
\text { nce if } \\
\text { Item } \\
\text { Delet } \\
\text { ed }\end{array}$ & $\begin{array}{r}\text { Correct } \\
\text { ed } \\
\text { Item- } \\
\text { Total } \\
\text { Correla } \\
\text { tion }\end{array}$ & $\begin{array}{r}\text { Cronba } \\
\text { ch's } \\
\text { Alpha } \\
\text { if Item } \\
\text { Deleted }\end{array}$ \\
\hline $\begin{array}{l}\text { Financial System and } \\
\text { Market Operation }\end{array}$ & 7,82 & 29,66 & ,647 & ,903 \\
\hline Investment Budgeting & 7,88 & 29,33 & ,746 & ,899 \\
\hline Financial Risks & 7,96 & 30,49 & ,607 & ,904 \\
\hline $\begin{array}{l}\text { Common/Compound/No } \\
\text { minal/Real Interest }\end{array}$ & 8,08 & 31,01 &, 621 & ,904 \\
\hline $\begin{array}{l}\text { Participation (Interest- } \\
\text { Free)Bank Differences }\end{array}$ & 7,84 & 30,50 &, 592 & ,904 \\
\hline Offshore Banking & 8,26 & 33,75 &, 147 & ,914 \\
\hline Bond-Bond Types/Repo & 7,84 & 28,91 & ,723 & ,900 \\
\hline $\begin{array}{l}\text { Interest/Exchange/Matur } \\
\text { ity/Risk } \\
\text { Management }\end{array}$ & 7,74 & 29,01 & ,722 & ,900 \\
\hline $\begin{array}{l}\text { Futures } \\
\text { (Forward)Markets }\end{array}$ & 7,90 & 29,89 & ,611 & ,904 \\
\hline $\begin{array}{ll}\text { Consumer } & \text { Credit, } \\
\text { Housing Credit } & \end{array}$ & 7,16 & 30,02 &, 562 & ,906 \\
\hline $\begin{array}{l}\text { Central } \\
\text { Transactions }\end{array}$ & 7,76 & 30,72 &, 523 & ,907 \\
\hline $\begin{array}{l}\text { Company's } \\
\text { Offering }\end{array}$ & 7,80 & 29,88 & 657 & ,902 \\
\hline Stock Exchanges & 7,72 & 30,00 & ,655 & ,902 \\
\hline Forex Markets & 8,16 & 31,40 &, 543 & ,906 \\
\hline Leasing & 8,16 & 31,93 & ,495 & ,907 \\
\hline Credit Note & 7,42 & 30,90 &, 516 & ,907 \\
\hline Derivative Products & 8,26 & 32,89 & ,396 & ,910 \\
\hline
\end{tabular}




\section{Analysis and Findings}

The Level of Knowledge Felt about Financial Concepts and Instruments

Table 5. Average Knowledge Level That Teachers Feel

\begin{tabular}{|c|c|c|c|}
\hline & $\begin{array}{r}\text { Aver } \\
\text { age } \\
50 \\
\text { Peop } \\
\text { le }\end{array}$ & $\begin{array}{l}\text { Deviation } \\
\text { from The } \\
\text { General } \\
\text { Average } \\
\text { Nominal }\end{array}$ & $\begin{array}{r}\text { Deviation } \\
\text { From } \\
\text { General } \\
\text { Average } \\
\text { Percentage }\end{array}$ \\
\hline $\begin{array}{l}\text { The Functioning } \\
\text { of The Financial } \\
\text { System and The } \\
\text { Market }\end{array}$ & 0,54 & 0,048 & $9 \%$ \\
\hline $\begin{array}{l}\text { Investment } \\
\text { Budgeting }\end{array}$ & 0,48 & $-0,012$ & $-3 \%$ \\
\hline Financial Risks & 0,4 & $-0,092$ & $-23 \%$ \\
\hline $\begin{array}{l}\text { Common/Comp } \\
\text { ound/Nominal/R } \\
\text { eal Interest }\end{array}$ & 0,28 & $-0,212$ & $-76 \%$ \\
\hline $\begin{array}{l}\text { Participation } \\
\text { (Interest-Free) } \\
\text { Bank } \\
\text { Differences } \\
\end{array}$ & 0,52 & 0,028 & $5 \%$ \\
\hline $\begin{array}{l}\text { Offshore } \\
\text { Banking }\end{array}$ & 0,1 & $-0,392$ & $-392 \%$ \\
\hline $\begin{array}{l}\text { Bond-Bond } \\
\text { Types/Repo }\end{array}$ & 0,52 & 0,028 & $5 \%$ \\
\hline $\begin{array}{l}\text { Interest/Exchang } \\
\text { e/Maturity/Risk } \\
\text { and Management }\end{array}$ & 0,62 & 0,128 & $21 \%$ \\
\hline $\begin{array}{l}\text { Futures } \\
\text { (Forward) } \\
\text { Markets }\end{array}$ & 0,46 & $-0,032$ & $-7 \%$ \\
\hline $\begin{array}{l}\text { Consumer } \\
\text { Credit, Housing } \\
\text { Credit }\end{array}$ & 1,2 & 0,708 & $59 \%$ \\
\hline $\begin{array}{l}\text { Central Bank } \\
\text { Transactions }\end{array}$ & 0,6 & 0,108 & $18 \%$ \\
\hline $\begin{array}{l}\text { Company's } \\
\text { Public Offering } \\
\end{array}$ & 0,56 & 0,068 & $12 \%$ \\
\hline Exchanges & 0,64 & 0,148 & $23 \%$ \\
\hline Forex Markets & 0,2 & $-0,292$ & $-146 \%$ \\
\hline Leasing & 0,2 & $-0,292$ & $-146 \%$ \\
\hline Credit Note & 0,94 & 0,448 & $48 \%$ \\
\hline $\begin{array}{l}\text { Derivatives } \\
\text { Products }\end{array}$ & 0,1 & $-0,392$ & $-392 \%$ \\
\hline Overall Average & $\begin{array}{r}0,49 \\
2 \\
\end{array}$ & 0 & $0 \%$ \\
\hline
\end{tabular}

When expressing the perception of information that teachers feel about financial concepts and instruments; they have been asked to give values that mean $0=\mathrm{I}$ don't know about this $1=\mathrm{I}$ have general knowledge of this subject $2=\mathrm{i}$ have more detailed information such as Risk, Cost and Returns. As it can be seen from the table, perception of information that teachers feel about financial concepts is low. The lowest knowledge level averages felt are respectively "coastal banking (off shore) and derivatives" with 0.1 , "forex markets and leasing" with 0.2 and "name/compound/nominal/real interest types" with 0.28 . The concepts and tools that participants felt were most knowledgeable are "consumer credit, housing credit" with a value of 1.2 and "credit note" with 0.94 . The higher awareness of these concepts can be explained by the use of more by individuals in daily life. According to the results of the analysis, these concepts and instruments are followed by the "stock exchanges", "interest/exchange/maturity risk and management", "the company's public offering and financial system" and "the functioning of the market".

Looking at the general assessment of the information felt for financial concepts and instruments, there is an average of 0.49 corresponding to almost the middle of two comments which are "I have no knowledge of this issue" and "I have knowledge on the general level".

Table 6. Average Knowledge Level Felt by Teachers by Sectoral Distinction

\begin{tabular}{|c|c|c|c|c|}
\hline & \begin{tabular}{|l|} 
Publi \\
c \\
Secto \\
r \\
Teac \\
hers \\
Aver \\
age \\
24 \\
Peop \\
le
\end{tabular} & $\begin{array}{l}\text { Private } \\
\text { Sector } \\
\text { Teachers } \\
\text { Average } \\
\text { 26 People }\end{array}$ & \begin{tabular}{|l} 
Public \\
Private \\
Differen \\
ce \\
Nomina \\
1
\end{tabular} & $\begin{array}{l}\text { Public } \\
\text { Private } \\
\text { Differen } \\
\text { ce } \\
\text { Percenta } \\
\text { ge }\end{array}$ \\
\hline $\begin{array}{l}\text { The } \\
\text { Functioning } \\
\text { of The } \\
\text { Financial } \\
\text { System and } \\
\text { The Market }\end{array}$ & 0,54 & 0,54 & 0,00 & $1 \%$ \\
\hline $\begin{array}{l}\text { Investment } \\
\text { Budgeting }\end{array}$ & 0,46 & 0,50 & $-0,04$ & $-8 \%$ \\
\hline $\begin{array}{l}\text { Financial } \\
\text { Risks }\end{array}$ & 0,46 & 0,35 & 0,11 & $32 \%$ \\
\hline $\begin{array}{l}\text { Common/Co } \\
\text { mpound/Nom } \\
\text { inal/Real } \\
\text { Interest }\end{array}$ & 0,29 & 0,27 & 0,02 & $8 \%$ \\
\hline $\begin{array}{l}\text { Participation } \\
\text { (Interest- } \\
\text { Free) Bank } \\
\text { Differences }\end{array}$ & 0,71 & 0,35 & 0,36 & $105 \%$ \\
\hline $\begin{array}{l}\text { Offshore } \\
\text { Banking }\end{array}$ & 0,04 & 0,15 & $-0,11$ & $-73 \%$ \\
\hline $\begin{array}{l}\text { Bond-Bond } \\
\text { Types/Repo }\end{array}$ & 0,58 & 0,46 & 0,12 & $26 \%$ \\
\hline $\begin{array}{l}\text { Interest/Exch } \\
\text { ange/Maturity } \\
\text { /Risk and } \\
\text { Management }\end{array}$ & 0,54 & 0,69 & $-0,15$ & $-22 \%$ \\
\hline $\begin{array}{l}\text { Futures } \\
\text { (Forward) } \\
\text { Markets } \\
\end{array}$ & 0,46 & 0,46 & 0,00 & $-1 \%$ \\
\hline $\begin{array}{l}\text { Consumer } \\
\text { Credit, } \\
\text { Housing } \\
\text { Credit }\end{array}$ & 1,38 & 1,04 & 0,34 & $32 \%$ \\
\hline
\end{tabular}




\begin{tabular}{|l|c|r|r|r|}
\hline $\begin{array}{l}\text { Central Bank } \\
\text { Transactions }\end{array}$ & 0,67 & 0,54 & 0,13 & $24 \%$ \\
\hline $\begin{array}{l}\text { Company's } \\
\text { Public } \\
\text { Offering }\end{array}$ & 0,63 & 0,50 & 0,13 & $25 \%$ \\
\hline Exchanges & 0,75 & 0,54 & 0,21 & $39 \%$ \\
\hline $\begin{array}{l}\text { Forex } \\
\text { Markets }\end{array}$ & 0,25 & 0,15 & 0,10 & $63 \%$ \\
\hline Leasing & 0,21 & 0,19 & 0,02 & $8 \%$ \\
\hline Credit Note & 1,04 & 0,85 & 0,20 & $23 \%$ \\
\hline $\begin{array}{l}\text { Derivatives } \\
\text { Products }\end{array}$ & 0,08 & 0,12 & $-0,03$ & $-28 \%$ \\
\hline $\begin{array}{l}\text { Overall } \\
\text { Average }\end{array}$ & 0,53 & 0,45 & 0,08 & $\% 14,94$ \\
\hline
\end{tabular}

In this section, the perception of information felt is examined in the distinction between public and private sectors. It has been observed that there is no significant difference in the concepts and instruments of "financial system and market functioning", "forward markets", "common/compound/nominal/real interest types" and "investment budgeting", respectively. In contrast, the most obvious difference was realized in the question of "participation (interest-free) bank differences". The average level of knowledge declared by teachers working in the private sector is 0.35 , while the average knowledge level declared in the public sector is $0.71 \%$ which corresponds $105 \%$ more. It was followed by concepts and instruments $63 \%$ "forex markets", $39 \%$ "stock exchanges" and "financial risks" and "consumer/housing loans" with a difference $32 \%$, in terms of the proportional difference between the coefficients of the two sectors. The private sector thought it was more knowledgeable about off shore banking by $73 \%$, followed by derivatives with a margin of $28 \%$ and interest/exchange rate/maturity/risk management with $22 \%$. When we look at the general average, the average level of knowledge declared by teachers working in the public sector is 0.53 , while it is 0.45 for the teachers who are working in private sector.

Table 7. Average Knowledge Level That Teachers Feel By Age Factor

\begin{tabular}{|l|c|c|c|c|}
\hline & $\begin{array}{l}\text { Avera } \\
\text { ge } \\
\text { Under } \\
\text { 30 }\end{array}$ & $\begin{array}{l}\text { Aver } \\
\text { age } \\
31- \\
40\end{array}$ & $\begin{array}{l}\text { Aver } \\
\text { age } \\
41- \\
50\end{array}$ & $\begin{array}{l}\text { Avera } \\
\text { ge } \\
\text { Over } \\
50\end{array}$ \\
\hline $\begin{array}{l}\text { The Functioning of } \\
\text { The Financial System } \\
\text { and The Market }\end{array}$ & 0,38 & 0,53 & 0,33 & 1,13 \\
\hline Investment Budgeting & 0,31 & 0,41 & 0,33 & 1,13 \\
\hline Financial Risks & 0,31 & 0,41 & 0,33 & 0,63 \\
\hline $\begin{array}{l}\text { Common/Compound/ } \\
\text { Nominal/Real Interest }\end{array}$ & 0,25 & 0,18 & 0,33 & 0,50 \\
\hline $\begin{array}{l}\text { Participation (Interest- } \\
\text { Free) } \\
\text { Differences }\end{array}$ & 0,50 & 0,41 & 0,56 & 0,75 \\
\hline Offshore Banking & 0,06 & 0,12 & 0,11 & 0,13 \\
\hline $\begin{array}{l}\text { Bond-Bond } \\
\text { Types/Repo }\end{array}$ & 0,38 & 0,29 & 0,33 & 1,50 \\
\hline
\end{tabular}

\begin{tabular}{|l|c|c|c|c|}
\hline $\begin{array}{l}\text { Interest/Exchange/Ma } \\
\text { turity/Risk and } \\
\text { Management }\end{array}$ & 0,44 & 0,47 & 0,44 & 1,50 \\
\hline $\begin{array}{l}\text { Futures (Forward) } \\
\text { Markets }\end{array}$ & 0,25 & 0,29 & 0,33 & 1,38 \\
\hline $\begin{array}{l}\text { Consumer Credit, } \\
\text { Housing Credit }\end{array}$ & 1,13 & 1,12 & 1,00 & 1,75 \\
\hline $\begin{array}{l}\text { Central Bank } \\
\text { Transactions }\end{array}$ & 0,63 & 0,59 & 0,44 & 0,75 \\
\hline $\begin{array}{l}\text { Company's Public } \\
\text { Offering }\end{array}$ & 0,50 & 0,53 & 0,44 & 0,88 \\
\hline Exchanges & 0,56 & 0,65 & 0,56 & 0,88 \\
\hline Forex Markets & 0,06 & 0,18 & 0,33 & 0,38 \\
\hline Leasing & 0,19 & 0,00 & 0,33 & 0,50 \\
\hline Credit Note & 1,00 & 0,94 & 0,56 & 1,25 \\
\hline Derivatives Products & 0,13 & 0,00 & 0,22 & 0,13 \\
\hline Overall Average & 0,42 & 0,42 & 0,41 & 0,89 \\
\hline
\end{tabular}

In the examination according to age factor, according to general average the age group over 50 is the leader with 0,89 . The average of teachers over the age of 50 is more than double the average that occurs when this group is excluded. The main financial concepts and instruments that increase the average of teachers over the age of 50 are "Financial System and Market Functioning", "Investment Budgeting", "Bond-Bond Types/Repo", "Interest/Exchange/Maturity Risk and Management", "Company's Public Offering", "Stock Exchanges", "Participation (Interest-Free) Bank Differences".

This result with direct proportion to life can be attributed to the participants' experience, level of knowledge and their use and being more familiar with these concepts and tools. The level of knowledge felt by groups under 30 and 31-40 were similar and this was 0.42 , closely followed by the 41-50 age group with a level 0.41 .

Table 8. Average Knowledge Level That Teachers Feel According To Gender

\begin{tabular}{|c|c|c|c|c|}
\hline & $\begin{array}{r}\text { Avera } \\
\text { ge } \\
\text { Man }\end{array}$ & $\begin{array}{r}\text { Aver } \\
\text { age } \\
\text { Wom } \\
\text { an } \\
\end{array}$ & $\begin{array}{r}\text { Man / } \\
\text { Woma } \\
n \\
\text { Differe } \\
\text { nce } \\
\text { Nomin } \\
\text { al }\end{array}$ & $\begin{array}{r}\text { Man / } \\
\text { Woman } \\
\text { Difference } \\
\text { Percentage }\end{array}$ \\
\hline $\begin{array}{l}\text { The Functioning } \\
\text { of The Financial } \\
\text { System and The } \\
\text { Market }\end{array}$ & 0,76 & 0,38 & 0,38 & $101 \%$ \\
\hline $\begin{array}{l}\text { Investment } \\
\text { Budgeting } \\
\end{array}$ & 0,71 & 0,31 & 0,40 & $130 \%$ \\
\hline Financial Risks & 0,52 & 0,31 & 0,21 & $69 \%$ \\
\hline $\begin{array}{l}\text { Common/Comp } \\
\text { ound/Nominal/R } \\
\text { eal Interest }\end{array}$ & 0,48 & 0,14 & 0,34 & $245 \%$ \\
\hline $\begin{array}{l}\text { Participation } \\
\text { (Interest-Free) } \\
\text { Bank } \\
\text { Differences }\end{array}$ & 0,57 & 0,48 & 0,09 & $18 \%$ \\
\hline
\end{tabular}




\begin{tabular}{|l|c|c|c|r|}
\hline $\begin{array}{l}\text { Offshore } \\
\text { Banking }\end{array}$ & 0,19 & 0,03 & 0,16 & $452 \%$ \\
\hline $\begin{array}{l}\text { Bond-Bond } \\
\text { Types/Repo }\end{array}$ & 0,57 & 0,48 & 0,09 & $18 \%$ \\
\hline $\begin{array}{l}\text { Interest/Exchang } \\
\text { e/Maturity/Risk } \\
\text { and Management }\end{array}$ & 0,86 & 0,45 & 0,41 & $91 \%$ \\
\hline $\begin{array}{l}\text { Futures } \\
\text { Forward) } \\
\text { Markets }\end{array}$ & 0,62 & 0,34 & 0,27 & $80 \%$ \\
\hline $\begin{array}{l}\text { Consumer } \\
\text { Credit, Housing } \\
\text { Credit }\end{array}$ & 1,24 & 1,17 & 0,07 & $6 \%$ \\
\hline $\begin{array}{l}\text { Central Bank } \\
\text { Transactions }\end{array}$ & 0,67 & 0,55 & 0,11 & $21 \%$ \\
\hline $\begin{array}{l}\text { Company's } \\
\text { Public Offering }\end{array}$ & 0,71 & 0,45 & 0,27 & $59 \%$ \\
\hline Exchanges & 0,76 & 0,55 & 0,21 & $38 \%$ \\
\hline Forex Markets & 0,43 & 0,03 & 0,39 & $1143 \%$ \\
\hline Leasing & 0,29 & 0,14 & 0,15 & $107 \%$ \\
\hline Credit Note & 1,00 & 0,90 & 0,10 & $12 \%$ \\
\hline $\begin{array}{l}\text { Derivatives } \\
\text { Products }\end{array}$ & 0,14 & 0,07 & 0,07 & $107 \%$ \\
\hline Overall Average & 0,62 & 0,40 & 0,22 & $55 \%$ \\
\hline
\end{tabular}

According to general assessment, the difference between men and women is in favor of men. When the average of men is taken, the perception of information about these tools and concepts is 0.62 . For women, the value of 0.40 was calculated. Although the average results are considered low for both groups, the average of men is $55 \%$ which is higher than the average of women. The fact that men are more interested in financial instruments and concepts and tend to follow financial markets more in their daily lives supports the results of this analysis.

Concerning teachers, it was observed that men feel more knowledgeable about every concept and tool than women. When the average difference of the two genders on each concept is expressed as a percentage; they were calculated as $1143 \%$ "forex markets", $452 \%$ "off shore banking", 245\% "name/compound/nominal/real interest types", $130 \%$ "financial risks" which are noteworthy. The closest level of knowledge felt by men and women was "consumer/home loan" where the difference was $6 \%$, "credit rating" where the difference was $12 \%$ and "bond-bond types/repo and participation (interest-free) bank differences" where the difference was $18 \%$.

\section{Conclusion and Discussion}

When the surveys about perception of knowledge of teachers about financial instruments and concepts were evaluated, generally low level results were found. Particularly in derivative products, off shore banking, forex markets and leasing issues, the results achieved were $0.1,0.2$ and they were very low. The reasons for this can be considered to be subjects that they are not used in daily life, rarely encountered or never countered, uninterested, or it can be thought that they are subjects that have not been involved in the education life of teachers. Consumer / housing credits with 1.2 and credit notes with 0.94 were the subjects with the most felt highest level of information. This is because they have concepts and tools that they use in their daily lives or that they have witnessed a lot.

When examination done under the headings of public and private sectors, teachers working in the public sector with a value of 0.53 feel more knowledgeable, while in the private sector this figure is calculated as 0.45 . Although the public sector feels more knowledgeable, both values are low. No matter which sector the participants work in, the information levels that the participants feel take place in the middle of these options: "I have general knowledge of this subject" and "I don't know anything about that". In terms of the level of knowledge felt, the closest result to the expression "2Risk, I have more detailed information such as costs and returns" was observed in the field of consumer/home credit with 1.38 in the public sector and 1.04 in the private sector. This is followed by the concept of a credit note.

When the results of the research are evaluated in terms of age groups, the level of knowledge about financial instruments and concepts of the group over 50 is at the top with 0.89 . This result can be based on the participants' level of knowledge and financial experience, which is directly proportional to their age. 0.42 in the age group below 30 and 31-40, in the 41-50 age group, a mean of 0.41 similarly is reached. Although values of 1 or more are found in areas such as consumer/home loan and credit rating, the level of knowledge felt especially in groups under 50 years of age is very low.

When the level of knowledge about financial instruments and concepts is evaluated by gender, men feel more knowledgeable with 0.62 . In women, this value was measured as 0.40 . The reasons for this difference include that men are more interested in finance and more likely to follow the financial agenda, and to be more involved in economic activities compared to the general public. The issues where the difference is most and least are explained in the related section.

In general, teachers' level of knowledge feeling about financial concepts and instruments is low. This is not a criterion for evaluating the professional success or competence of teachers. However, it can be considered that strengthening teachers on issues such as financial literacy will have a multiplier effect on society. This situation is related to both the fact that teachers are a big occupational group and that their impact areas such as the number of students they train are very wide. More comprehensive and increased number of samples can be carried out within the framework of the results of this research and different publications can be carried out.

The teachers' professional group should be addressed separately in terms of targets such as increasing the level of knowledge about financial concepts and instruments in society, increasing financial literacy levels, creating conscious consumer masses that can better interpret economic plane and events.

\section{References}

Aba Şenbayram, E. (2019). Finansal Okuryazarlık: Harran Üniversitesi Suruç Meslek Yüksekokulu Öğrencilerine Yönelik Bir Araştırma. Econharran Harran Üniversitesi İIBF Dergisi , 3. 
Alkaya, A., \& Yağl1, İ. (2015). Finansal Okuryazarlık Finansal Bilgi, Davranış ve Tutum: Nevşehir Hacı Bektaş Veli Üniversitesi İiBF Öğrencileri Üzerine Bir Uygulama. Uluslararas1 Sosyal Araştırmalar Dergisi , 8 (40), 585-599.

Bayrakdaroğlu, A., \& Bilge, S. (2018). Finansal Eğitimin Finansal Okur-Yazarlık Üzerindeki Etkisi: Muğla İlinde Kadınlara Yönelik Bir Araştırma. Sosyal ve Beşeri Bilimler Araştırmaları Dergisi , 114.

Bayram, S. S. (2014). Finansal Okuryazarlık ve Para Yönetimi Davranışları: Anadolu Üniversitesi Öğrencileri Üzerine Uygulama. Business \& Management Studies: An International Journal , $2(2), 105-135$.

Coşkun, S. (2016). Üniversite Öğrencilerinin Finansal Davranış Ve Tutumlarının Belirlenmesi: Finansal Okuryazarlık Algıları Üzerine Bir Araştırma. İnsan ve Toplum Bilimleri Araştırmaları Dergisi , 5 (7), 2247-2258.

Finansal Okuryazarlık ve Erişim Derneği. (tarih yok). Para Durumu. 5 14, 2019 tarihinde Para Durumu: https://www.paradurumu.com/yonetilsinbutceler/turkiyede-finansal-bilgiye-sahip-olanbireylerin-orani-artti-haberi-4459 taken from this adress

Yücel, S., \& Çiftçi, N. (2018). Üniversite Öğrencilerinin Finansal Okuryazarlık Düzeylerinin Bazı Demografik Değişkenler Açısından İncelenmesi. İnönü Üniversitesi Uluslararas1 Sosyal Bilimler Dergisi, 159. 